\title{
Experience of Computer Science Education Reform Based on Enterprise-University Cooperation
}

\author{
Xiaoyang $\mathrm{Fu}$ \\ Department of Computer Science \\ Zhuhai College of Jilin University \\ Zhuhai, China \\ dvndavidfu@vip.163.com
}

\author{
Hendry Feng \\ Project Manager \\ Achievo Information Technology Corporation \\ Shenzhen, China \\ Hendry.feng@achievo.com
}

\begin{abstract}
High education has been popular in China while the graduates will face the more and more employment pressure as well as the youths in China have got the better education than before. The pressure is mainly presented as the confliction between the college traditional education model and the professional structure of modern knowledge needed by enterprises. How to improve the professional knowledge structure and strengthen the employment competitiveness of college students is one of the significant research projects of high education reform. The paper introduces the blue print of the application style personnel training in the department of Computer Science, improving the knowledge structure and low professional practice level of undergraduates, promoting the practice talent through making good use of efficient reform measure, such as course practices of key lectures, comprehensive practices and real project practices of cooperation with enterprises. It is very important that win-win college-enterprise cooperation model which not only reduces the cost of training of intern students but also improves the employment ability of students should be set up efficiently by the education reform experience.
\end{abstract}

Keywords-high education; undergraduate education reform; college-enterprise cooperation model; application talent training program

\section{INTRODUCTION}

Popularizing the High Education improves the domestic overall cultural qualities as well as enlarges the educational population. However, in term of the 2013 graduate employment survey report, the graduates who have piled up late years will face the more and more employment pressures. The graduates have been up to 6.99 million which is the largest graduate numbers since 1949 in China. So it sounds rational that the graduates will face unprecedented employment pressure. However, it is paradox that a few of enterprises also complain to face recruitment pressure that it is difficult to employ some professional graduates late years. The double pressures significantly imply that the conflict between the university education which is incline to theory lecture other than sufficient professional practice and enterprise requirements that should master the more professional knowledge and possess problemsolving ability. So how to improve the professional knowledge structure and strengthen the employment competitiveness is the key strategy for every modern university [4]. Zhuhai College of
Jilin University, which is directed by the Board of directors, is ranked as third in independent college from 2013 research report of China university evaluation by the Chinese Alumni Network as well as entering the top list of independent college. How to train the application talents in independent colleges has been studying recent years [3][6]. In order to improve the employment competitiveness, many measures are taken in the Computer Science Department (CS) of Zhuhai college of Jilin University, such as organizing students for software initiative competition, introducing cooperation between college and enterprises, training application talents in term of guiding principles of "comprehensive, application and open", abiding by the development style which emphasize on both teaching and research aspects.

\section{THE RESEARCH OF EDUCATION REFORM STYLE}

In recent decades, the developments of the computer science technology and IT industries have been changed dramatically. In order to reduce the gap between college education and requirements of enterprises, the new education reform model is researched in the computer science department as follows:

\section{A. Holding Academic Seminars Used to Improve the Research Level of the CS Teachers}

In order to improve the teaching and research level of the teachers, the specific seminar is held regularly, including artificial intelligence, embedded system, information security and software engineering. Through encouraging the young teachers to present their initiative research results or novel thoughts in the seminar, the knowledge structure and technology of teachers are updated through academic exchange in seminars.

\section{B. Adding Curriculum Design to Strengthen the Practice Ability of Students}

In order to improve the practice ability of students, the comprehensive practice tutorials have been designed in term of different professional areas in the sixth semester, such as internet of things, intelligence information and digital media technology besides some curriculum designs after lectures, such as java programming and web application programming, etc. 


\section{Participating the Lanqiao Cup Software Development Competition and Training Excellent Students}

We regularly organize the software competition every year by $\mathrm{C} / \mathrm{Java}$ language programming, finding the excellent students for special training which is used to prepare to take part in the national software development competition. The four students took part in the "Lanqiao Cup" national software development competition in 2013. One student got the first reward in the java development group, the other two students got second and third rewards in the $\mathrm{C}++$ development group respectively. The overall learning atmosphere has been set up through the excellent presentation in the competition while the other students would like to work hard to realize their development dream.

\section{D. introducing College-enterprise Cooperation Style to Improve the Employment Competitiveness}

The Achievo Information Technology Company is one of the enterprises with which our department has cooperated since 2006. The software development intern base has been set up in the department in 2013, introducing the manage regulation of the software company, holding seminar of new technology routinely, strengthening the understanding of the technology development of enterprises, reducing the gap between the professional courses and enterprise professional requirements. The paper will propose the specific measures how to cooperate with enterprise in the third section.

\section{E. Training the Students for Postgraduate Qualifying Exam to Broaden the Range of Employment}

The training courses of postgraduate qualifying exam, which includes mainly computer science professional qualifying exam training, such as data structure, operation system, computer network and database, etc, has been set up in the sixth semesters in the department in order to improve the enrolment rate of postgraduate students. Meanwhile, the professional English course has been set up in the department in order to strengthen the comprehensive ability of English for oversea studying.

\section{COLLEGE-ENTERPRISE COOPERATION MODEL}

China government encourages universities to take services for the enterprises and society, using the enterprise-collegeinstitution development model. Meanwhile, not only the enterprise can recruit the appropriate employees from the intern base but also the universities can broaden the range of employment, which realize the win-win style cooperation between university and enterprise. The cooperation intern base has set up this year in the department with the Achievo Information Technology Company, which the flow chart is described as follows:

\section{A. Set up New Technology Lecture [2]}

The new lecture, Computer development new Technology, was set up in computer science department in 2012, involving with the new conception of software engineering and management experience. Typical enrolment ranges between 30-80 students, with majority from computer science and software engineering, some others are from network engineering. The lecture, which includes introduction of software development tools, software development flowchart, software testing tools and auto-testing technology, etc, would last 16 week, 4 hours every week Saturday. This course also frequently attracts a number of other department students who wish to update their knowledge structure and to use some of these techniques to solve their problems. By the end of this course, students are expected to understand the fundamental concepts of software development process, and be able to apply these concepts to specific problem areas.

\section{B. New Technology Seminar}

The new technology seminar will hold twice a month on Thursday. Combining with the research subjects, the teachers would introduce the cutting-edge technology that includes mobile app design, computation intelligence, network security, etc, which broadens the knowledge range and encourages students to participate in researches.

\section{Dummy Project training}

The web application and android mobile client projects designed by teachers and company employees are used to train the students practice talent, where projects have been completed according to specific time. The students could be chosen through the designed exam and project results so that the chosen students would take part in the real projects.

\section{Projects Mission Assignment}

The concepts that the real projects should be provide to the undergraduates are introduced by the Stanford University [1]. In the intern base, the students passed the dummy project training would be divided into several project groups, such as android mobile client development group, web application group, program testing group and software-requirementsanalysis group, etc. The group numbers, who are managed by project leaders, have to complete the project modules according project requirements. So students not only learn the common techniques from the courses, but also gain hands-on experience in applying these techniques to real-world applications through assignments and project work.

\section{E. Pre-research Projects}

Offered the company new technology and measures, the teachers and company researchers would organize the students as initiative technology group so that began to research the future application technology, such as big data analysis algorithm, cloud computation, machine learning and evolutionary computation, etc.

\section{APPLICATION TALENT TRAINING PROGRAM}

There are three professions in the computer science departments, which is computer science, software engineering, network engineering. The paper introduces the 2013 application talents training program of the computer science as follows:

Main disciplines: computer science and technology. 
Main courses: Circuits and analog electronics techniques, Advanced language programming, Digital logic circuits, Discrete mathematics, Principles of computer composition, Data structure, Operation system, database principles and applications, Software engineering, Java web application, etc.

Main practices: computer experiments, curriculum design, extra-curriculum activities, internship practices and graduation design.

The computer science professional students should be completed 170 credits for graduation, which includes general education courses (68 credits), basic discipline courses (54 credits), professional courses ( 23 credits) and practice courses ( 25 credits).

TABLE I. Class HOUR AND CREDITS ASSIGNMENT

\begin{tabular}{|l|l|l|l|l|}
\hline \multirow{2}{*}{$\begin{array}{l}\text { Vertical } \\
\text { structure }\end{array}$} & $\begin{array}{l}\text { Class } \\
\text { hours }\end{array}$ & rate & \multirow{2}{*}{ credits } & rate \\
\cline { 2 - 4 } & & $(\%)$ & $(\%)$ \\
\hline $\begin{array}{l}\text { General } \\
\text { education } \\
\text { courses }\end{array}$ & 1104 & 40.8 & 68 & 40 \\
\hline $\begin{array}{l}\text { Basic discipline } \\
\text { courses }\end{array}$ & 1086 & 40.2 & 54 & 31.7 \\
\hline $\begin{array}{l}\text { Professional } \\
\text { courses }\end{array}$ & 416 & 15 & 20 & 11.7 \\
\hline $\begin{array}{l}\text { Extra- } \\
\text { professional } \\
\text { courses }\end{array}$ & 96 & 4 & 3 & 1.7 \\
\hline Total & 2702 & 100 & 145 & 85.2 \\
\hline Practice courses & 25 credits, 800 class hours \\
\hline
\end{tabular}

Adding the practice courses in the application talent program can be used to improve the practice abilities of students. Meanwhile, adding one or two new technology lectures taught by the enterprise clerk can not only supplement the extra-curriculum knowledge but also understand the enterprise cultures. At present, there are 51 enterprises set up cooperation relationship with the computer science department now, besides the cooperation with Achievo Information Technology Company since 2006. The intern base with Achievo Information Technology Company was transferred from the company to our college in 2013, which not only relieve the burden of the enterprise but also set up the internal intern base in the department to be beneficial to students. The diverse options for graduates, which include participating in the postgraduate exam, going abroad for advanced study, employed by the IT enterprises and self-employed, are indispensible for improving the employment competiveness. Besides employed by the enterprises, some students have enrolled in the many universities for postgraduate education, such as Sun Yat-Sen University, Jilin University, etc. Over 77 students are chosen to go abroad for advanced education, including 36 students in the University of Högskolan i Gävle, Sweden, 4 students in the Herzing University, etc.
The employment rate of the computer science department promote about 5\% from 2009 to 2012 and some excellent students have been employed by the Tencent Technology Company, Kingsoft Technology Company, etc. as result of some measures of application education reform these years.

\section{CONCLUSIONS}

As the pilot project of industry-university-research cooperation, the education reform measures have been taken in the Computer Science department of Zhuhai college of Jilin University science 2006 , promoting solving problems abilities of students, broadening the professional knowledge and employment range, strengthening the employment competiveness. But the college-enterprise cooperation model is also face many challenges, especially involving the new technology courses adjustment, the insufficiency time of participating research for students, the lack funds of enterpriseuniversity cooperation. However, as the beneficial attempt of education reform, college-enterprise cooperation contributes to reform the traditional education ideas, reducing the gap between the talents requirements by company and traditional education conceptions. The popular technology and specific employment requirements could be learnt by exchange information between universities and enterprises. Adjusting appropriately the professional courses rate according to requirements of enterprises in the training program would contribute to training the application talents that enterprises have been eager for. Meanwhile, it is beneficial for enterprise to choose the employees from internship students and solve some technical problems by making good use of university research capacities through cooperation with universities. It is very important that win-win college-enterprise cooperation model which not only reduces the cost of training of intern students but also promotes the employment ability of students by the education reform experience.

\section{REFERENCES}

[1] CHEN Ding--fang, ZHANG An-fu. Jin Cheng, "Use Standford university's successful experience as Reference, search for teaching Innovations in our country's Universities of Science and Engineering," High Education Forum, vol. 6, pp. 35-38, December, 2008.

[2] Mengjie Zhang, "Experience of Teaching Computational Intelligence in an Undergraduate Level Course,"IEEE Computational Intelligence, 2011, pp. $57-59$.

[3] LI Yuanjing, WANG Chengzhang, "Analysis on the Current Situation of Higher Education Resource Allocation in China,"Eastern Acadamic Forum, 2009, pp. 161-165.

[4] Yan Cui, "Impact of modern educational technology on traditional education,"Joural of Beihua University(Social Science Edition), vol. 6, 2006(in chinese)

[5] Yu Benchen, Wang Rang, "Research on Application of Modern educational Technology in Improving the Education Quality," Eastern Acadamic Forum, 2011, pp. 23-26.

[6] Chen lingping, "Research on Application Talent Training Program of Independent University", University Education, July, 2013 